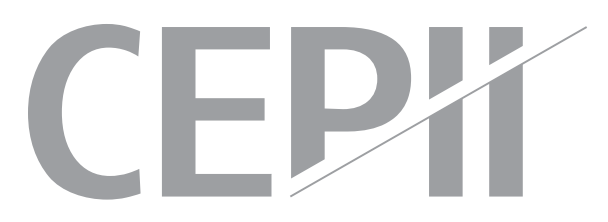

\title{
Measuring the Balassa-Samuelson Effect: A Guidance Note on the RPROD Database
}

Cécile Couharde, Anne-Laure Delatte, Carl Grekou, Valérie Mignon \& Florian Morvillier

\section{Highlights}

- RPROD is a global database that complements EQCHANGE, by providing additional measures of the Balassa-Samuelson effect.

- RPROD includes five measures of this effect based on: the relative GDP per capita, the relative labor productivity, the relative consumer-price-to-producer-price ratio, and two relative sectoral value-added deflators.

- These measures are provided for a wide range of countries (up to 182 economies, depending on the considered indicator), spanning from 1973 to 2018 and using several weighting schemes associated with each country's main trading partners. 


\section{Abstract}

This guidance note outlines the construction and contents of RPROD. This new database developed by CEPII complements the EQCHANGE database, by providing additional measures of the Balassa-Samuelson effect. RPROD delivers the following indicators computed for each country included in the database, and relative to its main trading partners: (i) GDP per capita, (ii) labor productivity, (iii) consumer-price-to-producer-price ratio, (iv) three-sectors' value-added deflator, and (v) six-sectors' value-added deflator. These different measures are publicly available (http://www.cepii.fr/CEPI//fr/bdd_modele/presentation.asp?id=34), with the aim to contribute to the investigation of the Balassa-Samuelson hypothesis, and to the comparison of estimated equilibrium real exchange rates and currency misalignments across alternative proxies of this effect.

\section{Keywords}

Balassa-Samuelson, Relative Productivity, Tradables, Non-tradables.

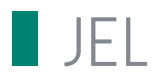

F31, F41.

Working Paper

\section{CEPI}

CEPII (Centre d'Etudes Prospectives et d'Informations Internationales) is a French institute dedicated to producing independent, policyoriented economic research helpful to understand the international economic environment and challenges in the areas of trade policy, competitiveness, macroeconomics, international finance and growth.
CEPII Working Paper

Contributing to research in international economics

(c) CEPII, PARIS, 2019

All rights reserved. Opinions expressed in this publication are those of the author(s) alone.

$\begin{array}{ll}\text { Editorial Director: } & \text { CEPII } \\ \text { Sébastien Jean } & \text { 20, avenue de Ségur } \\ & \text { TSA 10726 } \\ \text { Production: } & 75334 \text { Paris Cedex } 07 \\ \text { Laure Boivin } & +33153685500 \\ & \text { www.cepii.fr } \\ \text { No ISSN: } 1293-2574 & \text { Press contact: presse@ }\end{array}$




\title{
Measuring the Balassa-Samuelson effect: A guidance note on the RPROD database
}

\author{
Cécile Couharde*, Anne-Laure Delatte ${ }^{\dagger}$, Carl Grekou ${ }^{\ddagger}$, Valérie Mignon ${ }^{\S}$, and Florian \\ Morvillier
}

"EconomiX-CNRS, University of Paris Nanterre, France. Email: cecile.couharde@parisnanterre.fr.

${ }^{\dagger} \mathrm{CEPII}$ and EconomiX-CNRS. France. Email: anne-laure.delatte@cepii.fr.

${ }^{\ddagger} \mathrm{CEP} I I$ and EconomiX-CNRS, France. Email carl.grekou@cepii.fr.

${ }_{5}^{5}$ EconomiX-CNRS, University of Paris Nanterre and CEPII, France. Corresponding author: Valérie Mignon. EconomiX-CNRS. University of Paris Nanterre, 200 avenue de la République, 92001 Nanterre Cedex, France.

Phone: 33140975860 . E-mail: valerie.mignon@parisnanterre.fr

"EconomiX-CNRS, University of Paris Nanterre, France. Email: morvillier.florian@parisnanterre.fr. 


\section{Introduction}

The Balassa-Samuelson (BS hereafter) effect refers to the real exchange rate appreciation inherent in a catching-up process. Why are faster growth and continuing structural changes bound to affect the real exchange rate? The answer is found in two separate 1964 papers by Balassa and Samuelson (Balassa, 1964; Samuelson, 1964). These authors divide all goods in the world economy into two sectors: a tradable sector and a non-tradable sector which essentially supplies domestic residents. They show that when a country is catching up with the income levels in the more economically advanced economies, it will face a continuous real appreciation of its exchange rate.

How does this happen? The catching-up process implies that most of the productivity gains appear in the tradable sector. Since traded goods prices are determined in the global market, ${ }^{1}$ relatively faster productivity growth in the tradables will translate into rising wages in this sector that will also bid up wages in the non-tradable sector. However, the latter, facing smaller productivity increases than the tradable sector, cannot remain profitable if it accommodates such wages' growth. The solution is to raise prices faster for non-tradable goods. Thus, the supply-side reaction to the larger productivity increases in the tradable sector is to generate a higher rate of price inflation which, in turn, leads to an appreciation of the real exchange rate.

The BS effect being an equilibrium phenomenon, it is a key mechanism when investigating the dynamics of the equilibrium real exchange rate (see, e.g., Chinn, 1999). Indeed, as the real exchange rate behavior driven by the BS effect reflects the natural evolution of a catching-up economy, real appreciation will not necessarily imply for this economy a loss of international competitiveness. Over the last twenty years, the increased availability of high-quality data has allowed researchers to track the existence of the BS effect. ${ }^{2}$ This issue has been particularly analyzed in developing and emerging economies-as in Asian countries - that have been growing very rapidly in recent decades, transitioning to freemarket-oriented economies and gradually integrating with global markets (Ito, Isard, and Symansky, 1999; Drine and Rault, 2003; Choudhri and Khan, 2005; Qian, 2010; Hassan, 2016; Wang, Xue, and Du, 2016; Imai, 2018). Similarly, the catching-up process of transition economies - such as the Central Eastern European Countries that have joined the European Union or the Economic and Monetary Union-has raised concerns about the validity of the BS hypothesis in those countries (Halpern and Wyplosz, 2001; Égert, 2002; Égert, Drine, Lommatzsch, and Rault, 2003; Fischer, 2004; Mihaljek and Klau, 2004; Égert, Lommatzsch, and Lahrèche-Révil, 2006; Mihaljek and Klau, 2008; García-Solanes,

\footnotetext{
${ }^{1}$ That is, purchasing power parity (PPP) holds in the tradable sector.

${ }^{2}$ Note that, as a large body of articles on the subject has been published, we only cite the most recent and/or relevant papers.
} 
Sancho-Portero, and Torrejón-Flores, 2008). More recently, the BS hypothesis has also received renewed attention in developed economies (see, e.g., Cardi and Restout, 2015; Hassan, 2016; Zhang, 2017; Berka and Steenkamp, 2018; Berka, Devereux, and Engel, 2018).

To date, however, the issue of the BS effect has mostly concerned limited samples of countries. One reason for this is the absence of long series of internationally comparable productivity measures covering a wide geographical area. ${ }^{3}$ The RPROD database provided by the Centre d'Etudes Prospectives et d'Informations Internationales (CEPII) aims at filling this gap by delivering a series of internationally comparable measures of the BS effect over an extended sample of countries. While initially the EQCHANGE database (Couharde, Delatte, Grekou, Mignon, and Morvillier, 2018) relied on the most widely used measure to capture the BS effect-cross-country differentials in GDP (Gross Domestic Product) per capita-RPROD adds to this proxy four additional ones.

Specifically, the measures of the BS effect included in RPROD compare, for each country and its main trading partners, five distinct indicators that proxy trends in relative productivity of the tradable to non-tradable sectors. The first two indicators are respectively GDP per capita and labor productivity measured by GDP per worker, available for 182 countries over the 1973-2018 period. The third proxy, mainly available for advanced and some emerging countries, is the consumer-price index (CPI)-to-producer-price index (PPI) ratio. Finally, the last two indicators included in RPROD are based on three- and six-sectors' valueadded deflators. Our five measures of the BS effect use the weighting scheme of the EQCHANGE database, which takes into account different samples of trading partners and provides two alternatives to weight relative indicators: (i) time-invariant weights calculated respectively between 2008-2012 and 1973-2016, and (ii) a time-varying scheme based on non-overlapping five-year average weights.

By making publicly available a wide range of alternative measures of the BS effect, with global coverage, RPROD, as a complement to the EQCHANGE database, constitutes a useful tool to (i) document the presence of a catching-up process in developing/emerging countries and assess the robustness of the BS hypothesis, and (ii) contribute to the comparison of estimated equilibrium exchange rates and corresponding currency misalignments across alternative measures of the BS effect. It is important to have in mind that each proxy carries a different set of information. Therefore, we provide some empirical implications of

\footnotetext{
${ }^{3}$ Recently, the IMF has constructed an annual database of productivity in the traded and non-traded goods sectors but the geographical coverage includes only 56 countries (Mano and Castillo, 2015). The Groningen Growth and Development Centre of the University of Groningen has also developed a database that provides comparisons of productivity at a detailed industry level, the GGDC Productivity Level database. This database is, however, restricted to a set of thirty OECD countries (Inklaar and Timmer, 2008).
} 
each measure documented in the literature in order to guide the users of the database in their choice of indicators.

This guidance note outlines the construction and contents of RPROD by describing the proxies calculated and compiled by the CEPII to measure the BS effect. To this end, the rest of the paper is organized as follows. To set the stage, Section 2 proposes a simplified representation of the BS effect in order to identify its key underlying measures. Section 3 sets out the framework for calculating the five measures of the BS effect included in RPROD. Finally, Section 4 provides some concluding remarks.

\section{Identifying measures of the BS effect}

Before turning to define the different indicators included in the RPROD database, it is useful to first look at the basic measures of the BS effect.

\subsection{The intercountry relative price of non-tradable in terms of tradable goods}

One way of giving a very simplified representation of the BS effect is to take the example of two open economies - a catching-up economy and an advanced country-that produce two types of goods: tradable goods $(T)$ and non-tradable goods (NT). If we suppose that the price index ( $p$, expressed in logs) in each economy is a geometric average of traded and non-traded goods prices, log-differentiating the expressions for prices yields:

- In the catching-up economy:

$$
\dot{p}=\gamma \dot{p}_{N T}+(1-\gamma) \dot{p}_{T}
$$

- In the more advanced country:

$$
\dot{p}^{*}=\gamma \ddot{p}_{N T}^{*}+(1-\gamma) \ddot{p}_{T}^{*}
$$

where foreign variables (i.e., variables related to the trading partners) are flagged with a star and the - denotes the rate of change. $\gamma$ is the share of non-tradable goods in the consumption basket, assumed, for simplicity's sake, to be the same in the two economies.

The real exchange rate ( $q$, expressed in logs) between the two economies is, by definition, the nominal exchange rate adjusted by price levels:

$$
\dot{q}=\dot{s}+\dot{p}-\dot{p}^{*}
$$

where $s$ is the exchange rate defined in units of the currency of the advanced country per unit of the currency of the catching-up economy. 
Then, substituting (1) and (2) into (3) gives:

$$
\dot{q}=\dot{q}_{T}+\gamma\left[\left(\dot{p}_{N T}-\dot{p}_{T}\right)-\left(p_{N T}^{*}-\dot{p}_{T}^{*}\right)\right]
$$

Equation (4) indicates that the appreciation of the real exchange rate in the catching-up economy can arise from: (i) the increase in the relative price of tradable goods, $\dot{q}_{T}$, and (ii) the increase in the relative price of non-tradable in terms of tradable goods. Assuming that PPP holds for tradable goods, the appreciation of the real exchange rate in the catching-up economy stems from faster rise in the prices of non-tradables relative to tradables compared to the advanced economy.

The faster rise in the relative price of non-tradable in terms of tradable goods may come from a variety of factors. According to Balassa (1964) and Samuelson (1964), it results from higher relative productivity gains in the tradable sector in the catching-up economy.

\subsection{The intercountry productivity differential between the tradable and the non- tradable sectors}

Assuming that the production functions in the two sectors are of the Cobb-Douglas type, as in De Gregorio, Giovannini, and Wolf (1994) and Obstfeld and Rogoff (1996), we have:

$$
\begin{gathered}
Y_{T}=A_{T} L_{T}^{\alpha_{T}} K_{T}^{1-\alpha_{T}} \\
Y_{N T}=A_{N T} L_{N T}^{\alpha_{N T}} K_{N T}^{1-\alpha_{N T}}
\end{gathered}
$$

where $Y$ designates output, $L$ labor and $K$ capital. $\alpha$ represents the share of labor in the sectors' value-added, and $A$ denotes the total productivity of factors. Under perfect competition, prices in each sector are thus given by:

$$
\begin{gathered}
P_{T}=\frac{1}{A_{T}} W^{\alpha_{T}} R^{1-\alpha_{T}} \alpha_{T}^{-\alpha_{T}}\left(1-\alpha_{T}\right)^{-\left(1-\alpha_{T}\right)} \\
P_{N T}=\frac{1}{A_{N T}} W^{\alpha_{N T}} R^{1-\alpha_{N T}} \alpha_{N T}^{-\alpha_{N T}}\left(1-\alpha_{N T}\right)^{-\left(1-\alpha_{N T}\right)}
\end{gathered}
$$

where $W$ is the unit cost of labor and $R$ the rate of return on capital. If we consider the case of a small open economy with perfect capital mobility and $P_{T}$ as the numeraire, then 
PPP in the tradable goods sector ensures that the rate of return in tradables $(R)$ is equal to its world value. Log-differentiating the expressions for prices yields:

$$
\begin{aligned}
& \dot{p_{N T}}=-\dot{A_{N T}}+\alpha_{N T} \dot{W} \\
& \dot{p_{T}}=-\dot{A_{T}}+\alpha_{T} \dot{W}=0
\end{aligned}
$$

where variables in lowercase are expressed in logarithmic terms. Solving for the difference, the increase in the relative price of non-tradable in terms of tradable goods can be written in the catching-up economy as:

$$
\dot{p_{N T}}-\dot{p_{T}}=\frac{\alpha_{N T}}{\alpha_{T}} \dot{A}_{T}-\dot{A_{N T}}
$$

Assuming for simplicity that $\frac{\alpha_{N T}}{\alpha_{T}}$ is the same in the two economies, we have:

$$
\dot{p}_{N T}^{*}-\dot{p}_{T}^{*}=\frac{\alpha_{N T}}{\alpha_{T}} \dot{A}_{T}^{*}-A_{N T}^{*}
$$

Substituting (11) and (12) into Equation (4) yields the following expression of the appreciation of the real exchange rate:

$$
\dot{q}=\dot{q}_{T}+\gamma\left[\frac{\alpha_{N T}}{\alpha_{T}}\left(\dot{A}_{T}-\dot{A}_{T}^{*}\right)-\left(\dot{A}_{N T}-\dot{A}_{N T}^{*}\right)\right]
$$

Then, if PPP holds only for tradable goods, the appreciation of the real exchange rate in the catching-up economy will stem from faster relative productivity growth in the tradable goods sector compared to that of the advanced country.

\section{The RPROD database}

This section describes the construction of the different measures included in RPROD to assess the BS hypothesis, as well as the sources of data used in the calculations. Table A.1 in the Appendix indicates the country coverage of RPROD for each measure.

The simplified expressions of the BS effect described in Section 2 suggest that it can be measured by intercountry trend movements either in relative prices of non-tradable to tradable goods (Equation (4)) or in relative productivity of the tradable to non-tradable sectors 
(Equation (13)). However, in the absence of long series of internationally comparable total factor productivity measures and disaggregated prices, getting good proxies of the BS effect over an extended sample of countries is a challenge. It is also difficult to accurately separate the tradable and the non-tradable sectors as there is no direct measure of these sectors.

Given these constraints, RPROD adds four new measures of the BS effect to the EQCHANGE database. Because RPROD aims to have global coverage, the choice of these measures has been constrained by the data that can be collected over a large sample of countries. These measures are based on two sets of indicators: the first indicator relies on labor productivity (Section 3.1) and the three others, on relative prices-the CPI-to-PPI ratio, three- and six-sectors' value-added deflators (Section 3.2). All these indicators are multilateral and involve comparisons of a country with its main trading partners. Data on weights associated with each country's trading partners come from the EQCHANGE database which (i) takes into account two main groups of trading partners (i.e., 186 trading partners and the top 30 trading partners for each country), and (ii) includes two weighting schemes. The first one is time-invariant and consists of two weight sets respectively representative of foreign trade between (i) 2008-2012, and (ii) 1973-2016. The second weighting system is time-varying and is essentially based on non-overlapping five-year average weights (for more details, see Couharde, Delatte, Grekou, Mignon, and Morvillier, 2018).

\subsection{Productivity measures}

To assess the BS effect, total factor productivity (TFP) in the tradable and the non-tradable sectors should be in principle compared. However, this requires estimation of production functions at a disaggregated level which is only possible on a limited sample of countries. For example, Kakkar and Yan (2012) construct measures of sectoral TFP for six Asian economies (Hong Kong, Indonesia, Korea, Malaysia, Singapore, and Thailand) as Solow residuals (Solow, 1957) from constant-price domestic currency series of output, capital, labor shares and hours worked. Berka, Devereux, and Engel (2018) also provide a panel of traded and non-traded TFP levels for euro-area countries. When productivity growth in the non-tradable sector is assumed to be constant across countries-which is an assumption usually made in most studies - aggregate productivity measures may be employed as they are directly proportional to the tradable sector productivity. However, these measures also require estimation of production functions for each country, which represents an empirical challenge given the scarcity of capital stock data for many countries. ${ }^{4}$ Accordingly, many studies rely on relative GDP per capita as a proxy for relative productivity in the tradable sector (see Balassa, 1964; Rogoff, 1996; Chong, Jordà, and Taylor, 2012 among others).

\footnotetext{
${ }^{4}$ It should be noticed that version 8.0 of the Penn World Table introduces measures of capital stock and TFP since 1950 for a range of countries (https://www.rug.nl/ggdc/docs/capital_labor_and_tfp_in_ pwt80.pdf).
} 
RPROD reproduces time series on relative GDP per capita converted into dollars expressed in PPP terms already available in the EQCHANGE database. Data are collected from the Penn World Table (PWT) 9.0. We update these data and extend them to a larger set of countries (182) by using the World Development Indicators (WDI, World Bank) and the World Economic Outlook databases.

Denoting $B S \_g d p c$ the BS measure based on this first indicator, we get for a country $i$ at time $t$ :

$$
B S_{-} g d p c_{i, t}=\frac{G D P c_{i, t}}{\prod_{j=1}^{N}\left(G D P c_{j, t}\right)^{w_{i j, t}}}
$$

where $G D P c_{i, t}$ is the GDP per capita in constant 2011 PPP U.S. dollars of country $i$ at time $t$, and $w_{i j, t}$ is country $i$ 's trade-based weights for all its partners $j, N$ denoting the number of trading partners.

However, using GDP per capita as a proxy of productivity to measure the BS hypothesis implies introducing an additional assumption of a stable labor participation rate. This is why investigations of the BS hypothesis have also frequently been carried out relying on relative labor productivity in order to capture total-economy productivity differentials (see Hsieh, 1982; Marston, 1986; Canzoneri, Cumby, and Diba, 1999; Schnatz, Vijsellaar, and Osbat, 2004; Bénassy-Quéré, Béreau, and Mignon, 2009 among others).

In this respect, RPROD provides series of relative labor productivity. We measure labor productivity as GDP per worker in constant 2011 PPP U.S. dollars. This indicator presents the main advantage of being available for a wide range of countries over a large time period. GDP per person employed, expressed in PPP, is calculated using PWT 9.0 for the 19732014 period. ${ }^{5}$ The $2015-2018$ period is filled up using the International Labour Organization (ILOSTAT) database, which also provides the output per worker. ${ }^{6}$

Denoting $B S \_g d p w$ the BS measure based on this second indicator, we get for a country $i$ at time $t$ :

$$
B S_{-} g d p w_{i, t}=\frac{G D P_{i, t} / L_{i, t}}{\prod_{j=1}^{N}\left(G D P_{j, t} / L_{j, t}\right)^{w_{i j, t}}}
$$

where GDP $P_{i, t}$ is the GDP in constant 2011 PPP U.S. dollars of country $i$ at time $t$, and $L_{i, t}$ denotes total employment (number of engaged people) of country $i$ at time $t$.

${ }^{5}$ PWT 9.0 can be downloaded via the University of Groningen webpage at: https://www.rug.nl/ggdc/.

${ }^{6}$ ILOSTAT statistics are available at: https://www.ilo.org/ilostat/. 
Ricci, Milesi-Ferretti, and Lee (2013) and Caputo (2018) argue that using GDP per worker in assessing the BS hypothesis can be misleading. Indeed, if the catching-up country benefits from equal productivity growth in both the tradable and non-tradable sectors, the resulting rise of the output per worker will have in the BS framework a neutral effect on the real exchange rate.

\subsection{Relative prices}

To account for the aforementioned sectoral developments, various studies rely instead on the relative price of non-tradable to tradable goods to assess the relevance of the BS effect. Indeed, in the BS model, the relative price of non-tradable goods is predicted to be independent of preferences over tradable and non-tradable goods and completely determined by the total factor productivity differential between the two sectors.

\section{The CPI-to-PPI ratio}

A usual solution is to consider the ratio of the Consumer Price Index (CPI) to the Producer Price Index (PPI) for the home country relative to the CPI-to-PPI ratio for the country's major trading partners as in Alberola, Cervero, Lopez, and Ubide (1999), Alberola (2003), Bénassy-Quéré, Béreau, and Mignon (2009), and Ricci, Milesi-Ferretti, and Lee (2013). Following this strand of the literature, the RPROD database provides a dataset on the relative CPI-to-PPI ratio for a sample of 72 advanced and emerging countries (Table A.1 in the Appendix). ${ }^{7}$ The primary source for the $\mathrm{CPI}$ and PPI series is the International Financial Statistics (IFS) database from IMF. ${ }^{8}$ Additional sources for some countries are described in Table B.2 (for PPI) in the Appendix.

Specifically, denoting BS_cppi the BS measure based on the relative CPI-to-PPI ratio, we get for a country $i$ at time $t$ :

$$
B S_{-} c p p i_{i, t}=\left(c p i_{i, t}-p p i_{i, t}\right)-\sum_{j=1}^{N} w_{i j, t}\left(c p i_{j, t}-p p i_{j, t}\right)
$$

where $c p i_{i, t}$ and $p p i_{i, t}$ respectively denote the $\mathrm{CPI}$ and $\mathrm{PPI}$ of country $i$ at time $t$ expressed in logarithmic terms.

\footnotetext{
${ }^{7}$ The time coverage of this indicator is constrained by PPI data availability. For this reason, the CPI-to-PPI ratio is mainly available for advanced economies over the 1973-2018 period, while the time coverage is more sparse for other countries.

${ }^{8}$ For Argentina, for the years 2017 and 2018, we extract PPI from INDEC (Instituto Nacional de Estadisticida). For the sake of completeness, see also Couharde, Delatte, Grekou, Mignon, and Morvillier (2018) for additional sources regarding CPI series over the 1973-2016 period.
} 
The reasoning behind using this ratio is that it proxies changes in the relative price of non-tradables to tradables, as PPI mainly concerns tradables' prices, whereas CPI covers essentially non-tradables' prices.

To what extent does the use of relative prices instead of productivity measures affect conclusions on the BS effect and equilibrium exchange rates? Égert, Lommatzsch, and Lahrèche-Révil (2006) show that these two measures lead to opposite real exchange rates' behaviors for OECD countries. ${ }^{9}$ Likewise, Dunaway, Leigh, and Li (2009) find that the relative productivity variable measured by the CPI-to-PPI ratio instead of by relative GDP per worker leads to a decline in the undervaluation of the Renminbi real exchange rate by almost 24 percentage points. However, Alberola (2003) argues that, although the CPI-to$\mathrm{PPI}$ ratio is not completely satisfactory, it can be chosen as a proxy for relative sectoral productivity as long as an extended, reliable series for productivity is lacking.

\section{Sectoral value-added deflators}

A less approximate approach is to define the sets of tradable and non-tradable sectors. The relative price of non-tradables to tradables is then calculated by using sectoral deflators and by weighting tradables and non-tradables by their value-added shares in total output. This approach implies, however, some form of assessment to determine to what extent a sector can be qualified as tradable or non-tradable. ${ }^{10}$

Different methods of decomposition have been suggested in the literature. The first approach relies on measuring the "tradability" of a good which consists in evaluating the extent to which a good, or a set of goods, is actually traded. That is precisely the approach followed by De Gregorio, Giovannini, and Wolf (1994) who classify a sector as tradable when at least $10 \%$ of total production across all countries of their sample (14 OECD countries) is exported. ${ }^{11}$

A second approach attributes non-tradable goods to the service sector, and tradable goods to the primary and manufacturing sectors. This decomposition is usually considered as broadly consistent with De Gregorio, Giovannini, and Wolf (1994)'s tradability measure (Betts and Kehoe, 2001). However, as pointed out by Lombardo and Ravenna (2012),

\footnotetext{
${ }^{9}$ For those countries, relative price adjustments induce a real appreciation, while productivity gains lead to a depreciation of the real exchange rate.

${ }^{10}$ The difficulty of accurately separating the tradable and non-tradable goods sectors is also widely discussed in the literature focusing on the role of the relative price of non-tradable goods in accounting for real exchange rate fluctuations (see the seminal and most cited paper of Engel (1999)).

${ }^{11}$ Note that some studies (Bems, 2008; Lombardo and Ravenna, 2012) refine this tradability measure in two ways. First, they adopt a country-specific threshold, due to varying weights of the non-traded goods across countries (Engel, 1999). Second, they measure the tradability of a good according to the wholesale and retail trade sector (which, in this case, is assumed to produce non-tradable outputs).
} 
assuming all service industries as dealing in non-tradable goods has some drawbacks. Indeed, given that several services are increasingly traded internationally, this assumption can lead, in the case of most countries, to lower values of the tradable share in total output. The solution is to draw on a more disaggregated sectoral decomposition, as in some studies based on a six-sector disaggregation (MacDonald and Ricci, 2005; Lee and Tang, 2007; Ricci, Milesi-Ferretti, and Lee, 2013; Caputo, 2018).

Following this second approach, RPROD includes three- and six-sectors' value-added deflators to track the evolution of the relative price of non-tradables to tradables. The three-sectors' value-added deflator is based on the (i) agricultural, (ii) industrial, and (iii) services sectors. ${ }^{12}$ Total services are used to represent the non-tradable sector, whereas manufacturing and agriculture are taken together to represent the tradable sector (Choudhri and Khan, 2005; Bénassy-Quéré, Béreau, and Mignon, 2009).

For a country $i$, the price index of value added at time $t$ for each sector $k\left(P \vee A_{i, t}^{k}\right)$ is calculated by dividing the value added at current prices by the value added at constant prices in the accounting period and the considered sector, using 2010 as base year.

Denoting $B S_{-}$def 3 the BS measure based on three-sectors' value-added deflators, we get for a country $i$ at time $t$ :

$$
B S_{-} d e f 3_{i, t}=p v a_{i, t}-\sum_{j=1}^{N}\left(w_{i j, t} \times p v a_{j, t}\right)
$$

where $p v a_{i, t}$ is the value-added deflator of country $i$ expressed in logarithms: $p v a_{i, t}=$ $p v a_{i, t}^{\text {serv }}-\beta p v a_{i, t}^{\text {agr }}-(1-\beta) p v a_{i, t}^{\text {ind }}$; serv, agr and ind respectively denote services, agriculture and industry. $\beta$ is the share of agriculture in the tradable sector, computed as the ratio between agriculture value added and the total value added of agriculture and industry.

In the six-sector disaggregation, the following sectors are distinguished: (i) agriculture, hunting, forestry, fishing; (ii) mining, manufacturing; (iii) construction; (iv) wholesale, retail trade, restaurants and hotels; (v) transport, storage and communications; and (vi) other activities. ${ }^{13}$ Following De Gregorio, Giovannini, and Wolf (1994)'s classification, construction, wholesale, retail trade, restaurants and hotels, and other services are classified in the non-tradable sector, while agriculture, manufacturing, mining, utilities, and transport are treated as tradable goods.

\footnotetext{
${ }^{12}$ Agriculture corresponds to International Standard Industrial Classification (ISIC) divisions 1-5 and includes forestry, hunting, and fishing, cultivation of crops and livestock production. Industry corresponds to ISIC divisions 10-45, and services to ISIC divisions 50-99. See Table B.3 in the Appendix.

${ }^{13}$ The description of the divisions associated with each of these sectors is available in Table B.3 in the Appendix.
} 
To derive the six-sectors' deflator, we follow Lee and Tang (2007) and compute countryspecific weights for each sector $\left(\omega_{i, k}\right)$, measured by its value-added share in total output:

$$
\omega_{i, k}=\frac{\sum_{t=1}^{T} V A_{i, k, t}}{\sum_{k \in h}\left(\sum_{t=1}^{T} V A_{i, k, t}\right)}
$$

where $h$ denotes the nature of the sector $k$ under consideration, i.e., tradable $(T)$ or nontradable (NT) sector.

For each country $i$, the aggregated value-added deflator of the non-tradable $\left(p \vee a_{i, t}^{N T}\right)$ and tradable $\left(p \vee a_{i, t}^{T}\right)$ sectors is then calculated as a weighting average of value-added deflators for respectively all non-tradable sectors and all tradable sectors:

$$
\begin{gathered}
p v a_{i, t}^{N T}=\sum_{k \in N T}\left(\omega_{i, k} \times p v a_{i, t}^{k}\right) \\
p v a_{i, t}^{T}=\sum_{k \in T}\left(\omega_{i, k} \times p v a_{i, t}^{k}\right)
\end{gathered}
$$

where $p v a_{i, t}^{k}, p v a_{i, t}^{N T}$ and $p v a_{i, t}^{T}$ are expressed in logarithmic terms.

Denoting $B S_{-}$def6 the BS measure based on six-sectors' value-added deflators, we get for a country $\bar{i}$ at time $t$ :

$$
B S_{-} d e f \sigma_{i, t}=\left(p v a_{i, t}^{N T}-p v a_{i, t}^{T}\right)-\sum_{j=1}^{N} w_{i j, t}\left(p v a_{j, t}^{N T}-p v a_{j, t}^{T}\right)
$$

Data used to compute the pva series are extracted from the WDI database of the World Bank. The current and constant value added used to compute the six-sectors' value-added deflators are taken from UNCTAD. The proxy BS_def3 is available for the majority of countries until 2017, the starting date depending on the considered country. Turning to BS_def6, it is available over the 1980-2017 period for the majority of countries (see Table A.1).

It is worth mentioning that, as highlighted by Égert, Drine, Lommatzsch, and Rault (2003), the main problem in using relative price ratios is that their variation can also be caused by factors other than the BS effect such as higher demand for non-tradable goods, ${ }^{14}$ indirect

\footnotetext{
${ }^{14}$ To deal with the importance of demand-side considerations in explaining the evolution of the relative price
} of non-tradable goods, Asea and Mendoza (1994) use the Hodrick-Prescott filter in order to extract the 
taxes (which are included in the calculation of CPI but not in that of PPI), the adjustment of regulated prices (which mostly concerns non-tradables) and quality changes in non-tradables and tradables. This means that the resulting changes in the ratio of two price series can potentially be misinterpreted as reflecting changes in productivity. ${ }^{15}$

\section{Conclusion}

Empirical studies that estimate the BS effect usually provide conflicting evidence. As argued in the literature, these puzzling findings can be explained by the invalidity of the several underlying assumptions - such as law of one price in traded goods, intra-economy labor mobility, perfect capital markets and/or slow productivity growth in the non-tradable sector-which may undermine the prediction of the BS hypothesis. Alternatively, the puzzle can stem from empirical issues. The only way to check the BS hypothesis is to rely on proxies of productivity in the tradable and the non-tradable sectors. Identifying a BS effect may thus crucially depend on the choice of a particular measure.

This note focuses on this latter issue, by presenting the construction and contents of RPROD. This new database, which complements EQCHANGE, is the first attempt to provide several measures of the BS effect for a wide range of countries, spanning up to more than 40 years.

The RPROD database includes five distinct proxies of the BS effect. Regarding the first two measures, RPROD delivers consistent series of relative GDP per capita and relative labor productivity for 182 countries over the 1973-2018 period. The third measure relies on the relative $\mathrm{CPI}$-to-PPI ratio which aims at comparing changes in the relative price of non-tradable goods of a country to those of its trading partners. However, due to the weak availability of PPI series for developing economies, this indicator is mainly available for advanced and emerging countries. Finally, accounting for the existing literature, the RPROD database encompasses two measures based on tradable and non-tradable sectors' value-added deflators: the first one relies on a broad decomposition of tradable and nontradable goods based on the three following sectors: agriculture, industry, and services; and the second one relies on a narrower six-sector decomposition. Variants of these measures are also available according to different weighting schemes associated with each country's main trading partners.

long-run trends from short-run movements. More generally, testing a cointegration relationship between real exchange rates and relative prices provides a statistical way to separate the BS adjustment mechanism from short-term considerations.

${ }^{15}$ See also Engel (1999) for a list of the main drawbacks linked to the CPI-to-PPI ratio, and Chinn (2006) regarding the use of $\mathrm{CPI}$ as a measure of non-tradable prices. 
Although price indexes and productivity measures are provided consistently at a disaggregated level for the OECD countries, there is no such comprehensive coverage of industries and years for developing economies. Overall, the five indicators included in the RPROD database should be used mainly for sensitivity or robustness analyses when investigating the relevance of the BS effect and/or when estimating equilibrium exchange rates and corresponding currency misalignments. 


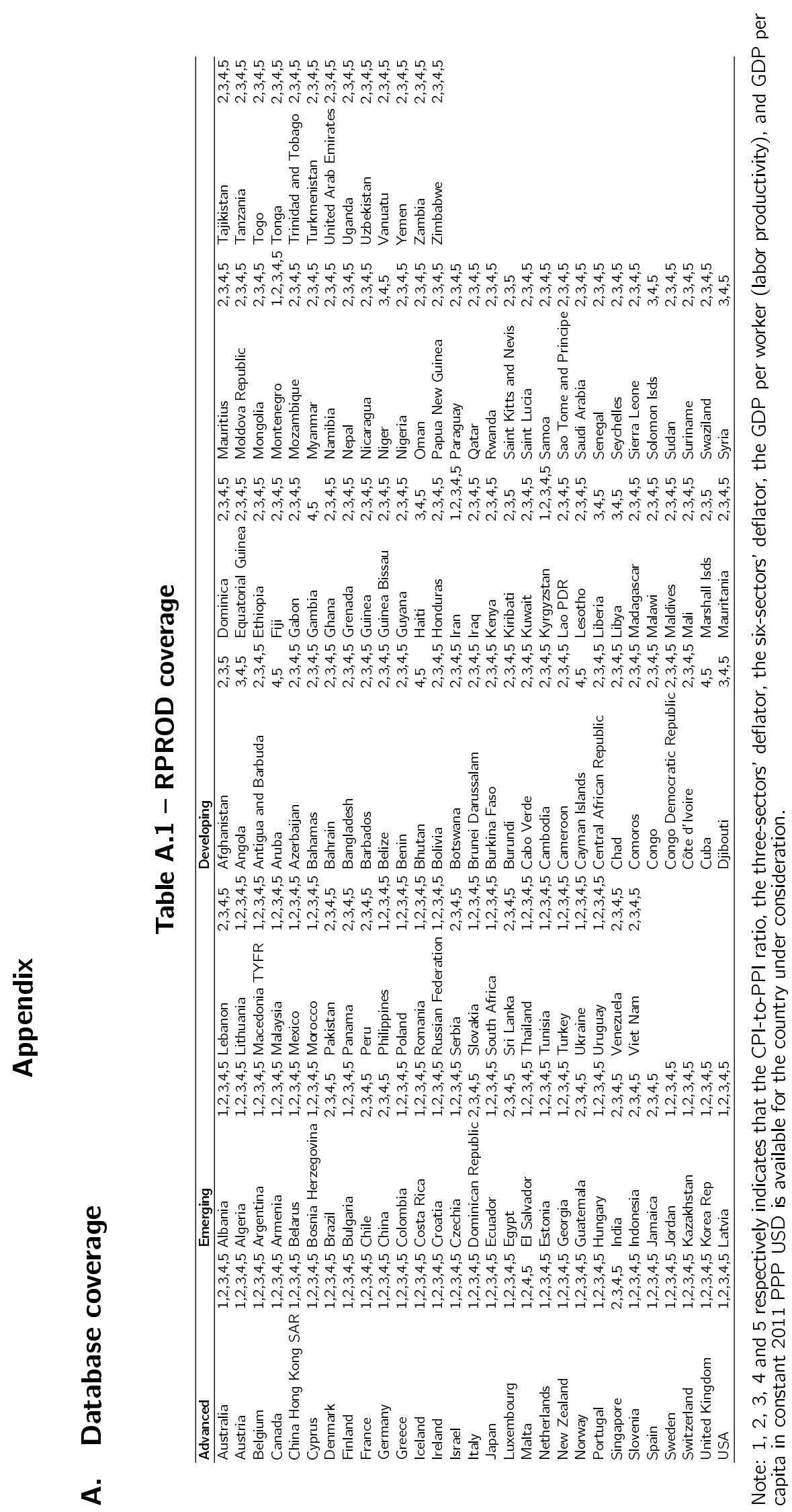




\section{B. Data: secondary sources}

Table B.2 - Producer Price Index (additional sources)

\begin{tabular}{ccc}
\hline Country & Period & Source \\
\hline Albania & 2017,2018 & INSTAT \\
Armenia & 2017 & ARMSTAT \\
Belarus & 2017,2018 & BELSTAT \\
Cyprus & 2017,2018 & GOVCY \\
El Salvador & $2015-2018$ & BCR \\
France & $1995-1998$ & OECD \\
Greece & $1981-1994$ & OECD \\
Israel & $1995-2018$ & OECD \\
Malta & 2017,2018 & NSO \\
Nicaragua & 2017 & BCN \\
Portugal & $1990-1999$ & OECD \\
Russia & $1998-2018$ & OECD \\
South Africa & $1973-1979$ & OECD
\end{tabular}

Notes:OECD: Organisation for Economic Co-operation and Development INSTAT: Institute of Statistics | http://www.instat.gov.al/

ARMSTAT: Armenia Statistical Committee of the Republic of Armenia | https://www.armstat .am/en/ BELSTAT: National Statistical Committee of the Republic of Belarus | http://www.belstat.gov.by/en/ GOVCY: Statistical service of the Republic of Cyprus http://www.mof.gov.cy/mof/cystat/statistics . nsf/index_en/index_en

BCR: Banco Central de Reserva de El Salvador | https://www.bcr.gob.sv/eng/ NSO: National Statistics Office/ https://nso.gov.mt/en/Pages/NSO-Home.aspx BCN: Banco Central de Nicaragua | https://www.bcn.gob.ni/ 
Table B.3 - Six sectors' classification

\begin{tabular}{ll}
\hline Sector & Divisions \\
\hline Agriculture, hunting, forestry, fishing & $01-05$ \\
Mining, manufacturing, utilities & $10-41$ \\
Construction & 45 \\
Wholesale, retail trade, restaurants and hotels & $50-55$ \\
Transport, storage and communications & $60-64$ \\
Other activities & $65-99$ \\
\hline
\end{tabular}

Source: International Standard Industrial Classification of All Economic Activities (ISIC), Revision 3.1, United Nations. 


\section{References}

Alberola, E. (2003): "Misalignment, liabilities dollarization and exchange rate adjustment in Latin America," Working Papers 0309, Banco de España.

Alberola, E., S. G. Cervero, J. H. Lopez, and A. J. Ubide (1999): "Global Equilibrium Exchange Rates; Euro, Dollar, "Ins," "Outs," and Other Major Currencies in a Panel Cointegration Framework," IMF Working Papers 99/175, International Monetary Fund.

Asea, P. K., and E. G. Mendoza (1994): "The Balassa-Samuelson Model: A GeneralEquilibrium Appraisal," Review of International Economics, 2(3), 244-267.

Balassa, B. (1964): "The Purchasing-Power Parity Doctrine: A Reappraisal," Journal of Political Economy, 72(6), 584-596.

Bems, R. (2008): "Aggregate investment expenditures on tradable and nontradable goods," Review of Economic Dynamics, 11(4), 852-883.

Bénassy-Quéré, A., S. Béreau, and V. Mignon (2009): "Robust estimations of equilibrium exchange rates within the G20: A panel BEER approach," Scottish Journal of Political Economy, 56(5), 608-633.

Berka, M., M. B. Devereux, and C. Engel (2018): "Real Exchange Rates and Sectoral Productivity in the Eurozone," American Economic Review, 108(6), 1543-1581.

Berka, M., and D. Steenkamp (2018): "Deviations in real exchange rate levels in the OECD countries and their structural determinants," Working Papers 2018-16, CEPII research center.

Betts, C. M., and T. J. Kehoe (2001): "Tradability of goods and real exchange rate fluctuations," Federal Reserve Bank of Minneapolis Staff Report.

Canzoneri, M. B., R. E. Cumby, and B. Diba (1999): "Relative labor productivity and the real exchange rate in the long run: evidence for a panel of OECD countries," Journal of international economics, 47(2), 245-266.

Caputo, R. (2018): "Real exchange rate appreciation after the financial crisis of 2008-2009: Misalignment or fundamental correction?," International Finance, 21(3), 253-272.

Cardi, O., and R. Restout (2015): "Imperfect mobility of labor across sectors: a reappraisal of the Balassa-Samuelson effect," Journal of International Economics, 97(2), 249-265.

Chinn, M. D. (1999): "Productivity, Government Spending and the Real Exchange Rate: Evidence for OECD Countries," in Equilibrium Exchange Rates, ed. by R. MacDonald, and J. Stein. Springer, Dordrecht.

(2006): "A Primer on Real Effective Exchange Rates: Determinants, Overvaluation, Trade Flows and Competitive Devaluation," Open Economies Review, 17(1), 115-143.

Chong, Y., Ò. Jordà, and A. M. Taylor (2012): "The Harrod-Balassa-Samuelson Hypoth- 
esis: Real Exchange Rates And Their Long-Run Equilibrium," International Economic Review, 53(2), 609-634.

Choudhri, E. U., and M. S. Khan (2005): "Real Exchange Rates in Developing Countries: Are Balassa-Samuelson Effects Present?," IMF Staff Papers, 52(3), 387-409.

Couharde, C., A.-L. Delatte, C. Grekou, V. Mignon, and F. Morvillier (2018): "EQCHANGE: A world database on actual and equilibrium effective exchange rates," International Economics, 156, $206-230$.

De Gregorio, J., A. Giovannini, and H. C. Wolf (1994): "International evidence on tradables and nontradables inflation," European Economic Review, 38(6), 1225-1244.

Drine, I., and C. Rault (2003): "Do panel data permit the rescue of the Balassa-Samuelson hypothesis for Latin American countries?," Applied Economics, 35(3), 351-359.

Dunaway, S., L. Leigh, and X. Li (2009): "How robust are estimates of equilibrium real exchange rates: The case of China," Pacific Economic Review, 14(3), 361-375.

Égert, B. (2002): "Estimating the impact of the Balassa-Samuelson effect on inflation and the real exchange rate during the transition," Economic Systems, 26(1), 1-16.

Égert, B., I. Drine, K. Lommatzsch, and C. Rault (2003): “The Balassa-Samuelson effect in Central and Eastern Europe: myth or reality?," Journal of Comparative Economics, 31(3), 552-572.

Égert, B., K. Lommatzsch, and A. Lahrèche-Révil (2006): "Real exchange rates in small open OECD and transition economies: Comparing apples with oranges?," Journal of Banking \& Finance, 30(12), 3393-3406.

Engel, C. (1999): "Accounting for US real exchange rate changes," Journal of Political Economy, 107(3), 507-538.

Fischer, C. (2004): "Real currency appreciation in accession countries: Balassa-Samuelson and investment demand," Review of World Economics, 140(2), 179-210.

García-Solanes, J., F. I. Sancho-Portero, and F. Torrejón-Flores (2008): "Beyond the Balassa-Samuelson effect in some new member states of the European Union," Economic Systems, 32(1), 17-32.

Halpern, L., and C. Wyplosz (2001): "Economic Transformation and Real Exchange Rates in the 2000s: The Balassa-Samuelson Connection," ECE Discussion Papers Series 20011, UNECE.

Hassan, F. (2016): "The price of development: The Penn-Balassa-Samuelson effect revisited," Journal of International Economics, 102, 291-309.

Hsieh, D. A. (1982): "The determination of the real exchange rate: The productivity approach," Journal of International Economics, 12(3-4), 355-362.

Imai, H. (2018): “China's rapid growth and real exchange rate appreciation: Measuring the 
Balassa-Samuelson effect," Journal of Asian Economics, 54, 39-52.

Inklaar, R., and M. P. Timmer (2008): "GGDC Productivity Level Database: International Comparisons of Output, Inputs and Productivity at the Industry Level," Discussion paper. Ito, T., P. Isard, and S. Symansky (1999): "Economic growth and real exchange rate: an overview of the Balassa-Samuelson hypothesis in Asia," in Changes in exchange rates in rapidly developing countries: Theory, practice, and policy issues (NBER-EASE volume 7), pp. 109-132. University of Chicago Press.

Kakkar, V., and I. Yan (2012): "Real exchange rates and productivity: evidence from Asia," Journal of Money, Credit and Banking, 44(2-3), 301-322.

Lee, J., and M.-K. Tang (2007): "Does productivity growth appreciate the real exchange rate?," Review of International Economics, 15(1), 164-187.

Lombardo, G., and F. Ravenna (2012): "The size of the tradable and non-tradable sectors: Evidence from input-output tables for 25 countries," Economics Letters, 116(3), 558561.

MacDonald, R., and L. A. Ricci (2005): "The real exchange rate and the Balassa-Samuelson effect: The role of the distribution sector," Pacific Economic Review, 10(1), 29-48.

Mano, R., and M. Castillo (2015): "The Level of Productivity in Traded and Non-Traded Sectors for a Large Panel of Countries," IMF Working Papers 15/48, International Monetary Fund.

Marston, R. C. (1986): "Real Exchange Rates and Productivity Growth in the United States and Japan," Working Paper 1922, National Bureau of Economic Research.

Mihaljek, D., and M. Klau (2004): "The Balassa-Samuelson effect in central Europe: a disaggregated analysis," Comparative Economic Studies, 46(1), 63-94.

(2008): "Catching-up and inflation in transition economies: the Balassa-Samuelson effect revisited," BIS Working Papers 270, Bank for International Settlements.

Obstfeld, M., and K. Rogoff (1996): Foundations of International Macroeconomics. MIT Press.

Qian, G. (2010): "The Balassa-Samuelson model of purchasing power parity and Chinese exchange rates," China Economic Review, 21(2), 334-345.

Ricci, L. A., G. M. Milesi-Ferretti, and J. Lee (2013): "Real exchange rates and fundamentals: a cross-country perspective," Journal of Money, Credit and Banking, 45(5), 845-865.

Rogoff, K. (1996): "The purchasing power parity puzzle," Journal of Economic Literature, 34(2), 647-668.

Samuelson, P. A. (1964): "Theoretical Notes on Trade Problems," The Review of Economics and Statistics, 46(2), 145-154. 
Schnatz, B., F. Vijsellaar, and C. Osbat (2004): "Productivity and the Euro-Dollar exchange rate," Review of World Economics, 140(1), 1-30.

Solow, R. M. (1957): "Technical change and the aggregate production function," The Review of Economics and Statistics, pp. 312-320.

Wang, W., J. Xue, and C. Du (2016): "The Balassa-Samuelson hypothesis in the developed and developing countries revisited," Economics Letters, 146, 33-38.

Zhang, Q. (2017): "The Balassa-Samuelson relationship: Services, manufacturing and product quality," Journal of International Economics, 106(C), 55-82. 